\title{
UPDATE OF PEDAGOGICAL VALUES IN THE PROCESS OF YOUNG TEACHERS' PROFESSIONAL DEVELOPMENT
}

Santa Striguna

Liepājas Universitāte

\begin{abstract}
There are values in every profession that are used by its representatives in their professional activity. Such values are important to those working in education, too. The actualization of educational values is to be especially emphasized in the professional development of young teachers. Educational institutions serve as examples for modeling of acquisition and implementation of values and attitudes, for pedagogy implies values later mastered by society. In order to ensure optimal results of the process, it is important to promote the development of young teachers' competencies for implementing innovations in acquisition of education and consolidate their functional and professional positions.
\end{abstract}

Key words: Pedagogical values, professional competence, young teacher.

\section{Introduction}

Predicting 21st-century priorities, most often education and knowledgeable society are referred to. The demand for people who are capable of growth, focus on their education level continuous development, are sufficiently flexible and willing to make efforts to find their place in a changing world is growing rapidly.

In a democratic society a person is viewed as the main value, the one who studies or works along with the other people. Respecting a person as the value of nowadays in the European countries, the society puts forward new challenges for the development of education. They are also topical in Latvia.

The aim of the research: based on the theoretical sources and pedagogical practice analysis raise the significance of the pedagogical values in the context of young teachers' socialization and professional development.

Each era is characterized by a specific understanding of the world and the surrounding reality. Today political and economic situation in the world is highly unstable. The end of the 20th century and the beginning of the $21 \mathrm{st}$ century is characterized by changes in all spheres of life-activity content and the rapid dynamics of the process, often by uncertainties, complexity, continuity, contradiction. In addition to that these changes are often uncritically accepted by the different groups of society. This fact complicates the process of educational value transfer from generation to generation in the situation of transformation, because when economic and political situations change, the earlier offered paradigm is also reconsidered. Latvia is one of the countries in the last twenty years, where these changes resulted in a significant resonance in all economic sectors, including education.

„The Latvian National Development Plan 2007 - 2013” (LR RAPLM, 2006) and „The Latvian Sustainable Development Strategy to the 2030" (Latvian 
Parliament, 2010) recognise a human being as Latvia's main resource, and education is one of the most significant factors to improve quality of life.

Latvian Sustainable Development strategic principles - creativity, tolerance, cooperation and participation, indicates the direction of the development of education that serves the development of personality that is characterized by a competitive higher education and science, creativity and entrepreneurial cultivation on all levels of education. The attainment of the educational objectives from the pedagogical point of view should be based on personal self-development (The Latvian Sustainable Development Strategy to 2030).

Council of Europe in the 'White Paper on education and training: towards a society that learns " talks of the need to create a future society which continually learns throughout their lives, so that every European citizen could find $\mathrm{him} /$ herself on the job market and professionally solve problems at work in the changing conditions set by rapid internationalization of the professions and work, globalization and information technology development.

Development of the country for a long time has been influenced by the higher education institutions, which are both the driving force and at the same time they also change (Bohm, 2008). Therefore, one can agree with the statement that "education must anticipate changes in society and with its variability be ahead of them". (Learning the Treasure Within, 1996)

The geopolitical location of the country, shortage of raw materials and energy resources define that the key factors in competitiveness of the Latvian people are their creative potential: an educated and skilled resident (Špona, Čamane, 2009). Education essentially determines the perspective of the human development, people's place and role in the world's cultural family. Latvian boom, logging and strengthening in the community of developed nations, is unlikely to take place without continuous improvement and development of national educational theory and practice .

According to A.Špona "society's aim is - to recognize man as the highest value and ensure everyone the opportunities for the realization of human potential" (Spona, 2004), it can be stated that a person growing and developing is also developing the human potential values that are obtained in the process of education and that can be categorized as educational values, such as a set of properties related to the human behaviour, life views, interests, beliefs, selfcompetence, cognitive needs, etc.

21st century education is described as:

- focused on the development of a free personality: a creative, independent, initiative, competitive, mobile;

- a world which is not sealed in itself;

- science based processes, the development of which has been rapid.

Along with that, the 21st century puts forward other requirements to the educator. $\mathrm{He} / \mathrm{she}$ has to possess such character features that allow to:

- be psychologically and practically capable of the rapid acceptance of new 
- scientific information;

- recognize and accept each student group behaviour singularity;

- capture, analyze, and evaluate conflicting information, different styles of thinking;

- successfully deal with a variety of non-standard situations and prevent the recurrence of certain educational situations;

- be open to value orientation change;

- analyse one's own and the students' performance, make an objective conclusion;

- identify one's own and the students' perspectives;

- be ready and realistically implement innovation in the practical pedagogical work;

- adapt continuous training and education of advanced technology, both domestic and foreign experiences and achievements to one's professional activities, students' individual features, interests and abilities.

The value of learning is not just the accumulation of knowledge and skills, but the transformation of the essential conditions for people to be able to act adequately in the environment around them.

Education should focus attention on the person, because he/she is the creator of knowledge (The Lisbon Strategy, 2004).

In the knowledge-based society to which we aspire, the main role is given to people, while more innovative economy requires new competencies, requiring the knowledge and skills to be continuously supplemented. University lecturer's professional activities mean work in the socially changing cultural context, promoting the quality of student learning within lifelong learning (Fulans, 2005).

In the context of changes not only a new specialist personal selfimprovement, self-realization and self-education process, content should be reviewed but also the quality and the practical realization of the true possibilities, contradictions, problems in the future specialist's personal and professional competence development. On the other hand, we should not forget that a key element of each person's competence basis is his/her self-experience.

This shows that the process of university study facing the challenges of the knowledge-based society, has to update a variety of professional development opportunities not only for students, a lecturer also has to define new pedagogical interaction goals, tasks and roles.

The most important research on teaching values in Latvia shows that education since the change of paradigm in last century, characterized by the transition from education as the eternal value that is obtained and is valid for life, provides stability and is recognised in the labour market ,to the need to learn throughout the whole life. Conducting the theoretical analysis of the study today's most significant educational values have been revealed (See Figure 1). 


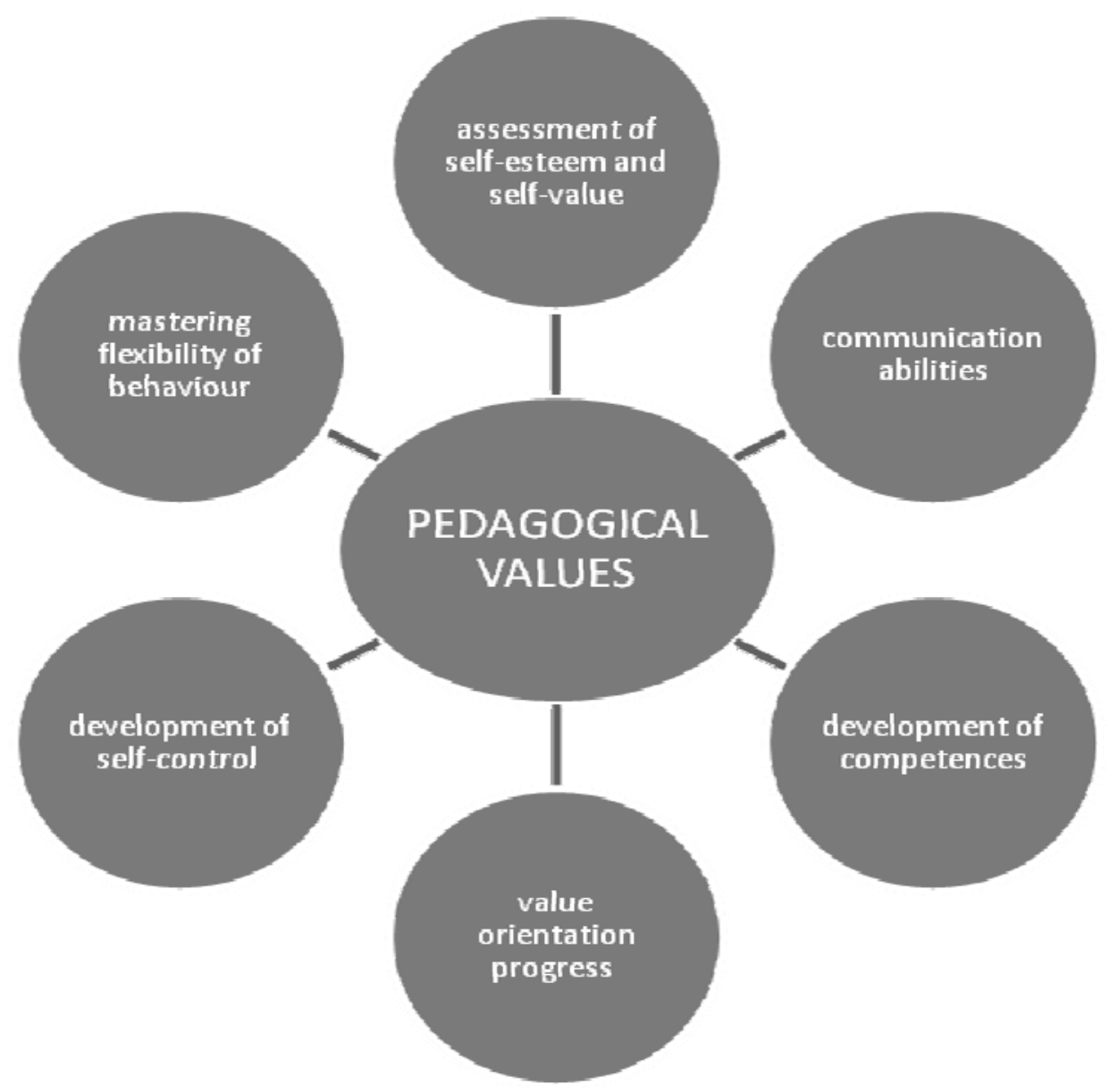

Figure 1.Diversity of pedagogical values

Higher educational institutions will remain as study and research sites, however, due to various changes in society they will become life-long learning institutions. Consequently, a lecturer at the University is not only the one who teaches, but who also learns. In addition, he/she learns from those whom he/she teaches and learns from what and how he/she teaches - learns within his/her professional activity. Therefore, further training process for university teachers should be organized in such a way that teachers identify their professional development needs and use opportunities to learn (Baranova, 2012).

A particular emphasis on values is placed in the process of the young teacher identity formation. Educational institutions serve as a model of learning and value acquisition, for modelling experience and attitude experience because Pedagogy brings values which later are implemented in the company.

Nowadays there is a growing demand for high-quality teaching knowledge, skills and abilities. It means a qualitative professional training for university teachers, advanced knowledge, and thus the opportunity for continuous selfeducation (Chernova, 2012).

As shown in Latvian statistical reports, the current Latvian university lecturers are in average 48 years old. The number of young teachers (with periods of service up to 10 years) in Latvian universities tends to increase (see Figure 2). 


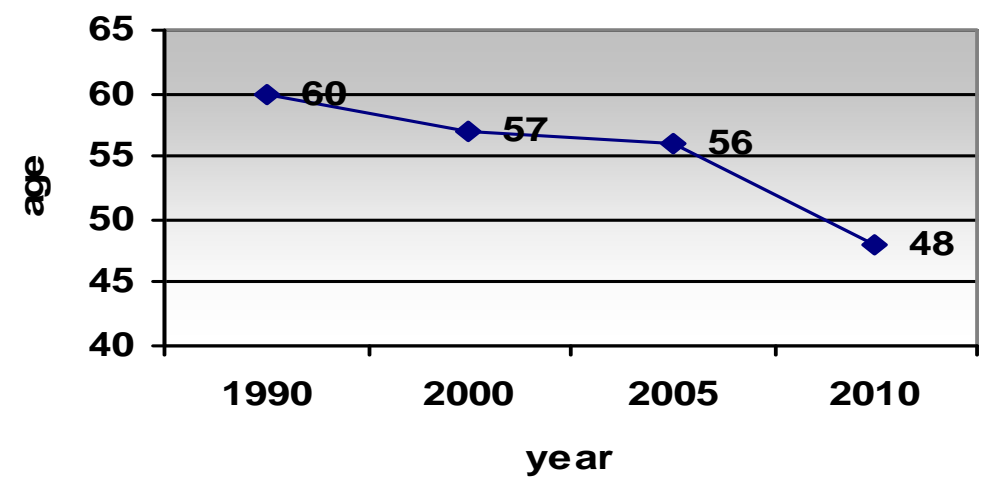

Figure 2. The average age of the teaching staff in Latvian universities

University lecturers' teaching competence and professional performance are the most important factors to ensure the learning process. In its turn qualitative education, providing the knowledge, abilities and skills contribute to the student as an individual's personal and professional growth.

Implementation of the study programs highlight the acquisition of the Life Skills and action competence approach to education, which are also important for teachers, therefore, the following teaching quality criteria can be considered as major:

- Life Skills as an ability to perceive and reflect corresponding to the external conditions positive behaviour, which allows to perform the demands of everyday life and accept life's challenges;

- the action competence to be able to apply the experience and understanding gained in the process of the knowledge, skills and attitudes acquisition.

In turn, the learning strategies determine:

- self-set actions;

- creative principle;

- research on the interest-based approach;

- integratively developing on past experience-based principle.

Liepaja University is one of the Latvian Republic universities, scientific and cultural symbol, which provides a competitive, internationally recognized variety of studies, develops innovative research, ensures sustainable development of the society, the knowledge in the field on Latvian economy, as a full partner in the united European education and science environment.

The document analysis reveals that the overall trend in Latvia - to increase the numerical ratio of the young teachers - is also characteristic to Liepaja University. The number of young staff by 1 January 2012 is $14 \%(n=18)$ of the total number of elected faculty teachers at the university $(n=107)$ (see Figure 3 ). 


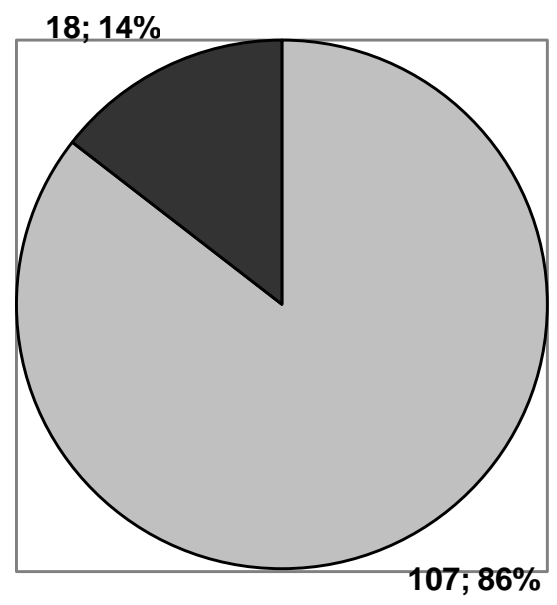

Figure 3. Percentage of young academic staff in Liepaja University

To find out what the young teacher professional development promoting and hindering factors in Liepaja University are a study in which young teachers were interviewed at Liepaja University and Riga Stradina University, with the total number of 30 , was conducted.

The research results reveal that the factors hampering the professional qualification are:

- lack of unified staff teams at faculties as well administrative units;

- lack of common understanding of the learning content, methodologies and tools;

- a rapid aging of educational infrastructure and teaching/learning materials.

In their turn, the following possibilities of professional qualification development were noted :

- the opportunity to participate in scientific research directions;

- opportunities for self-education within staff mobility programs, which allow to gain the knowledge provided by academic staff from universities in other European countries, promote the exchange of knowledge and experience in the fields of teaching strategies and techniques, provide an opportunity to expand and improve the range of courses offered and their content;

- "Doctoral School", in which the doctoral student can improve the necessary scientific skills, promote sectors cooperation and communication for conducting doctoral research, helps future doctoral students to assess their suitability for doctoral studies;

- an opportunity to present research results in scientific institutes and university faculties 'organized conferences;

- participation in research and educational projects.

Innovative and Practice based Education for Pedagogues and Professional Development of Mentors. (The aim: to promote the development of general education teacher competences, working out and implementing an innovative, 
flexible teacher training program as well as developing and strengthening mentor activities as the form of educational and professional development).

\section{Conclusions}

1. The knowledge society continually requires to set new accents in the organization of educational process. On the one hand, there are the needs of universities and students, on the other hand there is a kind of confusion, contradiction, inertia barriers, stereotypes in pedagogical thinking and action.

2. To ensure the optimal process of professional in-service training for young university teachers it is important to promote their functional and professional positions, as well as to encourage young faculty members' development in the field of professional competence in the implementation of innovation within the education process.

3. It is important to develop research areas and topics for research in accordance with national priorities in the process of individual research competence development, as well as to provide new scientific studies at all levels of study programs that are relevant to regional and social partners' needs.

\section{Kopsavilkums}

Tieši docētāju profesionālā darbība un tās pilnveide ir viens no studiju procesa kvalitātes noteicošajiem faktoriem. Jauno pedagogu profesionalitātes attīstī̌sana kvalifikācijas celšanas procesā pieprasa mērķtiecīgu un zinātniski pamatotu pedagoğiskās darbības kompetenču veidošanos un attīstīšanos, pilnveidojot un dažādojot docētāju profesionālās izaugsmes iespējas.

Augstas kvalifikācijas speciālista profesionalitāte iespējama tikai mērķtiecīgā pašpilnveides procesā, kurā ikviens, apzināti vairojot potenciālās spējas, dotības, intelekta attīstību, izziņas loka paplašināšanu, orientējas uz mūža izglîtību. Mērķtiecīgs pašizglītošanās process jauno docêtāju praksē ir profesionālās izaugsmes nosacījums un nemitīgi aktualizējama pedagoǵiskā vērtība.

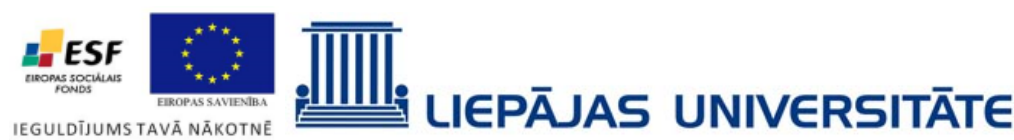

This work was partly funded by European Social Fund, project "Doktora studiju attīstība Liepājas Universitātē", grant No.2009/0127/1DP/1.1.2.1.2./ 09/IPIA/VIAA/018.

\section{Bibliography}

1. Baranova, S. (2012). Professional development of the university faculty in further education. The doctoral thesis in pedagogy science, University of Latvia.

2. Černova, E. (2012). Mediju pedagoǵiskā vērtība maǵistra studiju programmas apguvē: studentu vērtējums. Sabiedrība, Integrācija, Izglītība. Zinātnisko rakstu krājums. II daḷa Rēzekne, Rēzeknes Augstskola, 358.-364. 
3. Fullan, M. (2005). Leadership \& sustaiability: System thinkers in action. California.

4. Latvijas ilgtspējīgas attīstības stratēgija lìdz 2030.gadam. (2010) Retrieved on March 30 from www.latvija2030.lv/upload/latvija2030 saeima.pdf

5. Learning the Treasure Within. Report to UNESCO of the Inernational Commision of Education the 21th Century. (1996). Paris. Presses Universitaires de France.

6. Līdaka, A. (2007). Ieteikumi vērtībizglītības realizācijai I. Liepāja, LiePA.

7. Salīte. I. (2009). Ilgtspējīga izglītība demokrātijas un darbības pētījuma skatîjumā. Skolotājs 1/2009.8.-13.

8. Špona, A. (2004). Audzināšanas process teorijā un praksēe. Rīga, RaKa.

9. The Lisabon Strategy. Retrieved on March 30, 2012, from www.portal.cor.europa.eu

10. Valbis, J. (2005). Skolēna personības attīistība - izglìtības virsuzdevums. Rīga, Zvaigzne $\mathrm{ABC}$.

\begin{tabular}{|l|l|}
\hline Santa Striguna & Liepājas Universitāte \\
& Lielā iela 14, Liepāja LV-3402, Latvija \\
& E-pasts: santa.striguna@liepu.lv \\
& Tel. +371 63454949 \\
\hline
\end{tabular}

